\title{
INVESTMENT OF TEMPORARILY FREE RESOURCES OF CZECH SENIORS - PRESENT AND PERSPECTIVES
}

\author{
Josef NOVOTNÝ ${ }^{1}$, Jiři POLÁCH ${ }^{2}$
}

\begin{abstract}
The article deals with investment of Czech seniors into investment instruments. This article aims to find out how seniors invest in investment instruments in the Czech Republic and how much of their retirement they are willing to invest. The main problem that occurs in the investment environment in the Czech Republic is a reluctance to invest public investment. The result is the finding whether the seniors investors invest or not, including the introduction of new knowledge arising from research conducted at the chosen target group on the basis of the questionnaire survey. Investors in retirement are an important group of investors in terms of population, where their number is growing every year. The disadvantage of the elderly is often neglected investment company with regard to their age and income.
\end{abstract}

\section{KEY WORDS}

senior, income, age, investment instrument, model, investment.

\section{INTRODUCTION}

In the modern day, when the age boundary for old-age retirement has been pushed back, it is recommended that the current generation put aside part of their expenditures for investing in certain investment instruments. The reason for saving is to ensure respectable living conditions in old age after having finished an active working life.

One of the options offered to current as well as future senior citizens is to invest available financial resources in financial and real investments. Actualized investments can increase invested financial resources, which the investor can use for expenditures in old age or in the case of immediate need. It is assumed that resources that have been put aside will be used to preserve or increase the quality of living conditions via spa stays, travel or above-standard medical care, for example.

Current market conditions are not able to utilize the financial potential offered by today's senior citizens in the Czech Republic. Although this segment of consumers is not regularly engaged in employment, a certain percent does show willingness to further invest and increase the value of their available assets. Not utilizing this potential is the main problem arising from current market conditions. There are specific attributes that support this state, i. e., age and income.

\footnotetext{
${ }^{1}$ Correspondence address: Josef Novotný, Ing., Ph.D.; 466036246 ; josef.novotny@upce.cz: Studentská 95,53002 Pardubice, University of Pardubice, Faculty of Economics and Administration; www.uni-pardubice.cz

${ }^{2}$ Correspondence address: Jiří Polách, prof., Ing., CSc.; 595228 129, jiri.polach@vsp.cz, Michálkovická 1810/181, 71000 Ostrava, Ostrava Business School
} 
The goal of this article is to determine whether Czech senior citizens invest, if they are willing to invest, or any other possible factors limiting and discouraging investment. The main problem is not utilizing or appreciating the available financial assets that this segment has at hand. This is a segment of consumers which shows numerical growth each year.

It is necessary to start with the fact that certain senior citizens have just recently completed their active life and have spent part of their productive life within market conditions. Therefore, there is a definite assumption that they could have experience with investing, supported by the voucher privatization that the Czech Republic underwent in the 1990's. Empirical conclusions can be naturally supported by the success of implemented investment goals and further developments. On the other hand, voucher privatization and negative results from other implemented investment goals could actually discourage a large number of senior citizens for their entire lives.

A marketing research of a group of seniors living in the Czech Republic has been done to meet the established goals and to solve the main problem. Criterions of the research were predetermined.

\section{THE SENIOR CITIZEN INVESTOR TITLE}

In a number of advanced countries, this consists of key clients, because their number is growing, and it is expected that they will have a primary role on the market in the future, including determining trends. Nonetheless, this group of consumers is invariably omitted in certain countries with a developed market economy.

Riedl (2012, page 29) warns that a senior citizen is a customer for the future; he confirms this with seven statements aimed at marketing for senior citizens. This has been caused by societal development, which has affected certain sectors, e. g., products for children. Businesses that react in time to this population change gain a competitive advantage on the market. This statement is confirmed by Hartman, a manufacturer of children's diapers that experienced a market decrease in this specific segment. The company used the market's currently changing demographic conditions to its advantage and began to manufacture diapers for adults. "Today, they sell 1.3 billion items a year, and, in 2015 at the latest, it will be two billion."

Retirement is very important for senior citizens, because their living standard is dependent on this and, as a result, their willingness to invest. However, there are significant differences in retirement among senior citizens. These differences are caused by employment, profession, education and other factors which influenced the current amount of their retirement income.

Vlachynský (2013) points to differences primarily caused by economic inequality, though not only for senior citizens; he considers the influence to be mainly global risks from macroeconomic and microeconomic perspectives. From the macroeconomic perspective, this is the standard of a country's inhabitants, which is expressed predominantly by one indicator, i. e., GDP. The microeconomic perspective considers retirement inequality from within the context of the individual country. 


\subsection{Senior Citizen Investment in the Czech Republic ${ }^{3}$}

In the Czech Republic, senior citizen investment is not widespread and is lacking any kind of conception for investing in the future. The negative stance towards investment is caused by a range of factors which reflect investment goals. One of these is voucher privatization, which, even today, arouses mostly resentment and disappointment in today's senior citizens. With respect to the fact that negative information spreads quickly and is passed from generation to generation, it is very difficult to compel current, or even future, senior citizens to invest, for example, in stocks. These words are confirmed by Sejkora (2013), who writes literally that society sees trading in securities and mostly with company stocks as wheeling and dealing not as a legal way to appreciate their available financial assets.

In contrast, Syrový (2012, page 37) emphasizes the risk that annuitants are exposed to when investing. One of these risks is the growth of living costs via inflation. For annuitants who are retired, expenses can increase on account of changes in their state of health, which can be supported by further cost increases dependent on special aids, nursing services, etc. Another risk is long life span. "One of the options to protect against this risk is to arrange for insurance that guarantees that the insurance will pay a fixed annuity for the rest of a person's life." The last risk is inefficiency and a decline in the markets, which creates fluctuation in property value. Therefore, it is good to create an investment portfolio that diversifies risk.

The greatest satisfaction in life for seniors is having a sufficient financial base including property; however, this satisfaction is supplemented by the specific senior citizen's education. When these attributes are fulfilled, it results in senior citizens having better psychological states and more active personal lives. (Bočková, 2011)

In fact, demographic studies and prognoses should become the trigger impulse for investing in the Czech Republic. This current state should create ways in society for citizens of all groups of all ages - from productive to senior - to invest. Not dealing with this imminent problem would be hazardous to the future of human kind in old age, which could lead to conflict between generations (Gruss, 2009). Dvořáčková (2012) builds on this theory, putting emphasis on possible changes in the Czech Republic's demographic structure during the next sixty years due to long lifespan and low birthrate. A number of authors, i. e., Bartoňová (2010), Klufová (2010) and Roubíček (1997), are concerned, either peripherally or in detail, with the problematic of demographic development, its situations and characteristics. Demography and an aging population proves to be a significant problem; the government has therefore created national programs for resolving the investigated problematic, e. g., the Czech National Programme of Preparation for Ageing of 2008-2012 (2008).

However, on the other hand, it is necessary to actively engage financial institutions in order to create an investment environment for the senior segment in the Czech Republic. This is confirmed by Tůmová (Peníze, 2009), who says that the two million citizens here older than 60 is naturally a small investment base for monetary institutions on the Czech market. Despite this, certain of these institutions already offer products directly made for pensioners, i. e., Komerční Banka, which offers the PROGRAM SENIOR package. A number of banks admit that special products for senior citizens tend to be lacking. (Bankovní poplatky, 2012)

Savings appears to be another insufficiency, because a majority of income is absorbed by necessary expenses. If it is still possible for an individual to put aside a part of their expenses for savings, the

\footnotetext{
${ }^{3}$ There is a lack of literary sources directly focussed on investment of senior population. That is the reason why mainly Internet sources, which are not completely sufficient too, are used in the article.
} 
amount does not regularly exceed 1,500 CZK per month, as shown by the Deposit Insurance Fund's research. (Investujeme, 2013) Although small amounts remain for seniors to invest, professionals exhort Czech senior citizens to invest boldly and thereby increase their savings. Czechs of retirement age are much more careful with their investment goals; this is seen in the fact that they invest in low-interest investment instruments. (Idnes, 2013)

When a senior citizen is financially secure in old age, they are able to utilize high-quality services offered on the market. The current day offers business opportunities in sectors aimed at senior citizens, because it is assumed that most of them will use their savings to live out the rest of their lives under dignified conditions. (Podnikatel, 2013) However, in order for seniors to live their lives under suitable living conditions, it is necessary for them to start creating savings and investing them in real and financial investments in time. (Polách, 2012)

\subsection{Senior Citizen Investment in North America ${ }^{4}$}

Other countries are also concerned with the problematic of the senior citizen population. North America was chosen to evaluate investment options, because the most developed form of capitalism can be found here, namely in the United States of America. Although Canada and the USA are countries that have been long founded on market principles of economic development, even these countries deal with certain problems similar to those senior citizens encounter in the Czech Republic - senior population growth, investment, eliminating fraud, etc.

In Canada, they warn of the problematic of citizens that were born between 1946 and 1964, because these represent the largest group of investors. In the next decade, it is expected that senior citizens will control $70 \%$ of investment activities in this country, and, in 2030, it is presumed that they will represent $20 \%$ of the overall population of Canada. Here, the problematic is further examined so that this segment of consumers does not become victims of financial fraud such as, for example, a Ponzi scheme. (Canadianmoneysaver, 2014) It is recommended that Canada's aging population invest in the following investment instruments, i. e., bonds, guaranteed investment certificates, dividend stocks, annuities and stocks. (Canadianliving, 2014)

In contrast to this, citizens are able to have retirement income from more sources in the USA; most commonly, these are social security, income from savings, investment and part-time employment. The average income in retirement from these activities reached 31,742 USD in 2012 and concerned citizens 65 and over. If an American senior citizen does not have sufficient financial resources from the above options, then it is recommended that they stay employed part-time in order to preserve living standards. (Money Retirement, 2014) Other areas where seniors are recommended to invest are gold futures, coins or bars as well as government bonds, which have a reliable government rating. Because senior citizens are limited by age, it is therefore good to invest in short-term investments such as certificates of deposit or money market funds. (Caregivers, 2014) Another safe investment recommended for American seniors is certificates of deposit, because they are completely insured and protect this group of investors against loss of principal, interest and even against bank collapse. Treasury securities continue with this type of investment; they are similarly supported by the US government and are considered the safest investment. The last type recommended for senior citizens are GNMA (Government National Mortgage Association) bonds a type of bond that is covered by mortgage loans and is also supported by the US government like the previous two investment instruments; these are thus very safe sources of income not only for seniors. (Ehow, 2014)

\footnotetext{
${ }^{4}$ As well as in the Czech Republic, there is a lack of foreign-language literature dealing with matters of investment of seniors abroad, therefor only internet sources are used too.
} 
The USA is considered the country with the most highly developed form of market capitalism and thus also financial services provided. The senior population segment is not forgotten here, which a range of companies can attest to. The problematic is supported by publishing activities, including informational websites concerned with investment, such as ECONOMICTIMES (2010), MONEYOVER55 (2014), BUSINESS STANDARD (2013) and SENIOR LIVING (2014). An important document for senior citizens on the American financial market is the Guide for Seniors: Protect Yourself Against Investment Fraud, which protects senior citizens in the field of financial investment and which precisely describes: how not to become a victim of financial fraud, what the most common forms of fraud are, when to turn for help, etc. (SEC, 2014)

\section{RESEARCH METHODOLOGY}

For determining the conditions and options for Czech senior citizen investment, research was conducted at the beginning of 2014. The research concept came out of current theoretical and empirical findings relating to the problematic of senior citizen investment. The senior citizen population segment was chosen for research purposes, because this is the segment of the future, mainly because of the number of residents and the assets generated. Scientific methods were specified for preparing the research and model construction. The main method was analysis, which was used for background research of literature related to the investigated problematic concerning investing in investment instruments. A survey with questionnaire was part of the research. The senior segment was chosen according to previously established criteria, and it was used for conducting empirical research; quantitative research built on this to confirm or overturn the set hypothesis. Another method used was modeling, resulting in the creation of a model - Senior Investment Potential; it can be used during decision-making by company management as depicted in Fig. 1. The principles of logic and logical thinking were also used when conducting research and evaluating results, data and the proposed model.

\section{Figure 1 Senior Investment Potential}

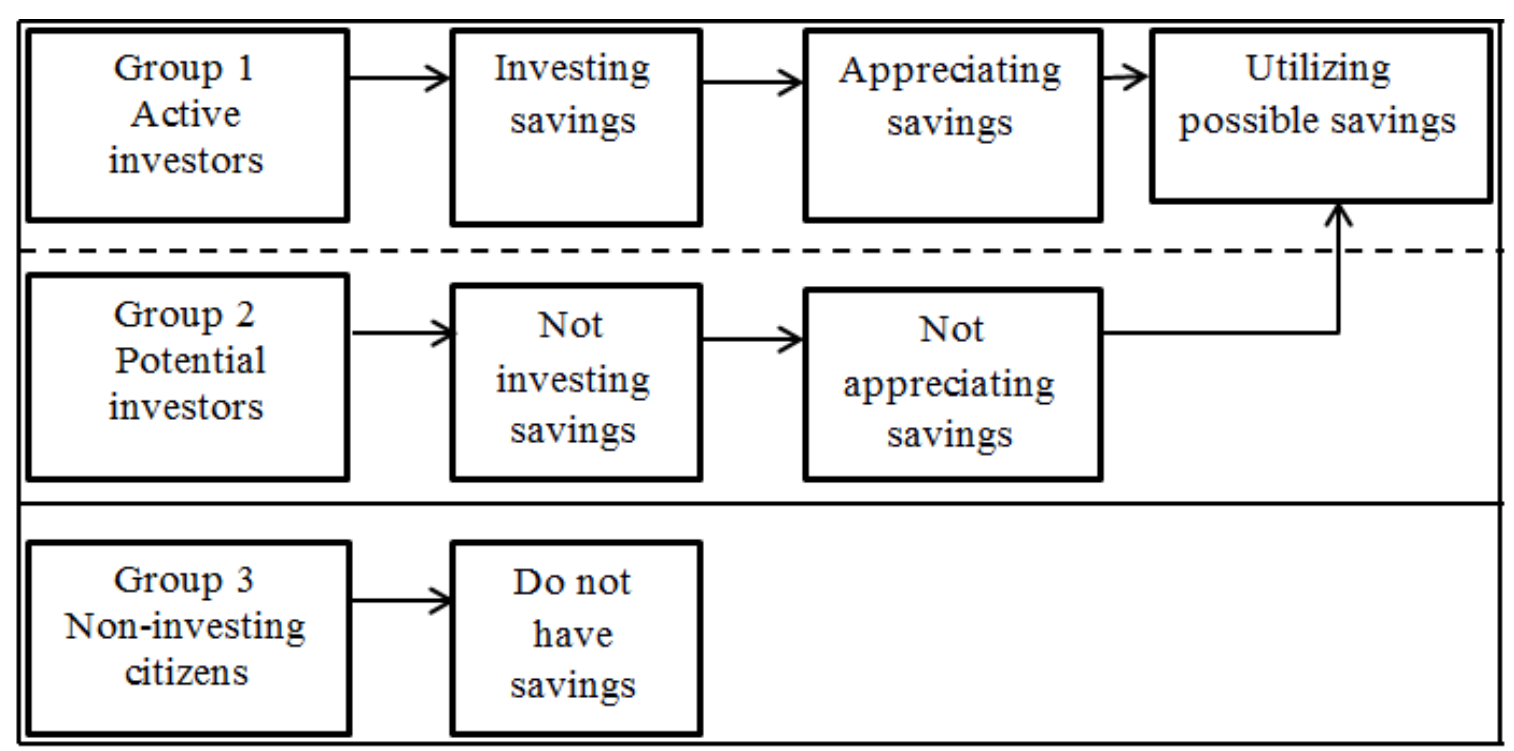

(Source: Own)

As seen from the model, the first group is composed of senior investors who actively use their saved financial assets allowing them to further appreciate, thereby generating their own assets. The second group is composed of potential investors who do not use their investment potential to generate 
further assets for themselves. The goal is to get these investors into the model's first group so that they can evaluate their investment options. The last group is composed of non-investing citizens who do not have savings. The possibility of enabling these citizens to get into the higher groups is very small. As a rule, these people are limited, for example: by serious disease, executions or low old-age pension. Therefore, they are designated as non-investing citizens in the model.

\section{THE CHARACTERISTICS OF RESEARCH CONCERNING SENIORS}

First, criteria were defined for the conducted research. Age, residence, citizenship and territorial specifications were included. The condition for including respondents in the research was that they fulfill the listed criteria, i. e., receiving an old-age pension, being 60 years or older and being a Czech citizen with permanent residence in the region of Svitavy. After establishing the criteria, the sample number of respondents was calculated according to the formula for an unknown composition of respondents presented by Kozel (2006).

$n \geq \frac{\mathrm{z}^{2} \times \mathrm{p} \times \mathrm{q}}{\Delta^{2}}$

where $\mathrm{n}$ - is the minimal number of respondents

$\mathrm{p}$ and $\mathrm{q}$ - are the number in percentages of respondents familiar with the problematic, i. e., tending towards the first variant (p) and unfamiliar, i. e., tending towards the second variant (q); if this number is not precisely known, we must make the maximum product of $\mathrm{p} \mathrm{x} \mathrm{q,}$ therefore $50 \%$ x 50\%,

$\square \square \square \square$ is set by us as maximum permissible error

$\mathrm{Z}$ - is the critical value of normalized normal distribution at the chosen level of significance.

For calculation of the minimum sample size, reliability was set at $90 \%$, where we find the selected quantile of normalized normal distribution for construction as $90 \%$ of the confidence interval value at 1.645. (Hindls, 2006) Permissible error was set at 10\%, and the following result was attained on the basis of this data:

$n \geq \frac{1.645^{2} \times 0.5 \times 0.5}{0.1^{2}}$

$n \geq 67.65$

On the basis of the calculation, it is necessary that a minimum of 68 or more respondents participate in the research according to the established criteria. The research was conducted randomly with the help of a personal questionnaire from January to March 2014 and 97 corresponding questionnaires were received that fulfilled the specified criteria. The final number of correctly filled-in questionnaires was considered to be sufficiently representative, because the number was higher than the final result of the calculated sample for minimum respondent sample size.

\subsection{Evaluating the Questionnaire}

The questionnaire was composed of five parts. The first part was aimed at verifying the established criteria. One of these criteria was the respondent's age, and the questionnaire was divided into four groups according to age. Of the participating respondents, $32 \%$ were in the 60 to 65 age category, the 66 to 70 category had the same percent, i. e., $32 \%$, the 71 to 75 group was $27 \%$, and the least amount of respondents were in the category of 76 and above, i. e., $9 \%$.

The second part was composed of questions where the seniors could express their personal opinion on investing without taking into consideration whether or not they invest. The first of the questions to which the seniors were able to respond was phrased in the following way: "Do you think that savings products are more appropriate for you than investment products?" The majority of the 
respondents said yes at an overall relative response of $72 \%$. Of these, they most frequently $-37 \%-$ chose the option that savings products are safer and have the option of depositing small and irregular monetary amounts; $20 \%$ added age considerations to this, and the last option was personal pension, which $15 \%$ of respondents chose. However, $28 \%$ of respondents listed a negative response to this question, because they leaned towards the option that each investment product has its own advantages and disadvantages. The second question relying on the respondents' opinion concerned financial and real investments. The question was worded in this way: "Do you prefer financial investments over real investments?" The option listed by the respondents with the highest number for this question was that it depends on the concrete investment at $38 \%$, close behind this answer was that they preferred real investment at $37 \%, 21 \%$ recommended a combination of real and financial investments and $4 \%$ preferred financial investments.

The third part of this questionnaire was aimed at courses on financial investment for senior citizens. The first question in the third section verified personal experience with taking courses. The research question was phrased in this way: "In the past five years, have you taken any courses in investing?" At $94 \%$, most answered that they haven't taken that type of course, $3 \%$ went only once, $1 \%$ went only twice, and $2 \%$ of respondents went more than twice. The next question tied in to this with respondents having to respond to the question: "What kind of professionals should lead courses specifically for seniors?" The senior citizens mostly preferred the combination of professionals from academia and companies concerned with this problematic at a rate of $49 \%$, following this was professionals only from companies at $27 \%$, from academia $23 \%$ and other areas $1 \%$. The next question was aimed at respondents' willingness and travel distance concerning a free course in investing. The question was as follows: "Would you welcome a free course in investing?" Of respondents, $51 \%$ were interested if the distance was $20 \mathrm{~km}$ or less, $2 \%$ if it was $50 \mathrm{~km}$ or less and no respondents were willing to travel more than $50 \mathrm{~km}$. However, this question was given a negative response, and a lack of interest in a free financial course was shown by $47 \%$ of respondents.

The next-to-last part of the questionnaire was aimed at missing elements in the investment environment and reasons for lack of interest, including financial fraud within the investigated group of respondents. The first of these elements concerned reacting to: "What do you feel is lacking the most within the Czech investment environment?" Investment products made specifically for senior citizens were lacking at $39 \%$, a professional approach by firms at $18 \%$, most respondents listed a combination of the previous questions (lack of products and firms' approach) at $41 \%$, and only $2 \%$ listed other elements. Following up on lacking elements was neglect of the investigated group on the financial market: "Do you think that Czech senior citizens are neglected in the area of investing?" That they were overlooked because of age was listed by $24 \%$, because of income was $13 \%$, most frequently chosen was the preferred combination of age and income at $56 \%$. Only $7 \%$ listed that they do not feel neglected in the area of finance. The last question in this part was aimed at financial fraud. The research question verified: "Have you ever been a victim of financial fraud in the past?" Experience with this base practice was listed by $14 \%$ of respondents including $11 \%$ with loss up to $10,000 \mathrm{CZK}$ and $3 \%$ with loss up to 50,000 CZK. None of the respondents listed loss above 50,000 CZK. However, $86 \%$ of seniors, the majority of the investigated group, listed that they had never been victims of financial fraud.

In the last section of the survey, questions were asked that had the purpose of testing the three set hypotheses. All the hypotheses mentioned were verified by the same test, including the same significance level - alfa 0.05 . This was a one-sided hypothesis concerning relative frequency, where we want to determine whether the relative frequency is significantly greater than 0.5 . (Pecáková, 2011) 
$U=(p-\pi o) / \sqrt{\frac{\pi o(1-\pi o)}{n}}$

where $\mathrm{n}$ - is normalized normal distribution

$\mathrm{p}$ - is determined relative frequency from the sample

$\mathrm{W}$ - is the critical field (for $\square=0.05$ ): $\mathrm{U} \square 1.645$

The data for the tested hypotheses are listed in Tables 1,2 and 3, including the calculation and position for verification or refutation of the listed hypotheses.

Hypothesis 1

"More than half of Czech senior citizens have experience with investment in the past." For purposes of refuting or proving the investigated hypothesis, seniors were asked the following question: "Have you ever invested in investment instruments, e. g., stocks, bonds or share certificates?" Seniors were given a number of options for answering the research question; they are listed in Table 1.

\section{Table 1 Experience with Investment in the Past}

\begin{tabular}{|c|c|c|}
\hline Experience with investing & Absolute frequency & Relative frequency (\%) \\
\hline Yes, in the past & 47 & $\mathbf{4 8}$ \\
\hline Yes, I am investing currently & 6 & $\mathbf{7}$ \\
\hline I have been considering doing it this year & 0 & 0 \\
\hline No, I have never tried it & 44 & 45 \\
\hline Total & $\mathbf{9 7}$ & 100 \\
\hline
\end{tabular}

(Source: Own)

$$
U=(0,55-0,5) / \sqrt{\frac{0,5(1-0,5)}{97}}=0,98
$$

The results of the test value $\mathrm{U}$ shows it to be smaller than 1.645 , therefore, we do not dismiss $\mathrm{H}_{0}$. We were not able to show that more than half of Czech senior citizens had experience with investing in the past. It is possible to state that the set hypothesis was not proven.

Hypothesis 2

"The majority of Czech senior citizens have financial resources for investing in investment instruments." The following question was posed to respondents for verifying or refuting the second hypothesis: "Are you able to set aside a monthly amount from your current personal pension or savings to put into investment instruments?" The respondents were given a number of options for answering the investigated question; results are listed in Table 2.

Table 2 Investing Part of Personal Pensions and Savings

\begin{tabular}{|c|c|c|}
\hline Investment of pension and savings & Absolute frequency & Relative frequency (\%) \\
\hline Yes, up to 500 CZK & 31 & $\mathbf{3 2}$ \\
\hline Yes, up to $1,000 \mathrm{CZK}$ & 30 & $\mathbf{3 1}$ \\
\hline Yes, more than $1,000 \mathrm{CZK}$ & 9 & $\mathbf{9}$ \\
\hline No & 27 & 28 \\
\hline Total & $\mathbf{9 7}$ & 100 \\
\hline
\end{tabular}

(Source: Own) 
$U=(0,72-0,5) / \sqrt{\frac{0,5(1-0,5)}{97}}=4,31$

The result of the test value $\mathrm{U}$ is greater than 1.645; therefore, we dismiss $\mathrm{H}_{0}$ and accept the alternative hypothesis. We were able to show that the majority of Czech pensioners do have financial resources for investing and the set hypothesis was proved.

Hypothesis 3

"The majority of Czech senior citizens are mostly turned away from investment because of distrust - uncertainty about the investment environment supported by the occurrence of fraud and difficulty enforcing the law." For refuting or confirming the third hypothesis, respondents were asked this question: "What do you think drives Czech senior citizens away from investing in investment instruments?" The respondents were given a number of possible answers for the question, with the results listed in Table 3.

Table 3 Factors Preventing Investors from Investing

\begin{tabular}{|c|c|c|}
\hline Factors preventing investors from investing & Absolute frequency & Relative frequency (\%) \\
\hline Distrust of the investment environment & 48 & $\mathbf{4 9}$ \\
\hline Uncertainty of return on investments & 22 & $\mathbf{2 3}$ \\
\hline Ignorance of the problematic of investment & 18 & 19 \\
\hline Other life priorities - grandchildren, travel & 9 & 9 \\
\hline Total & $\mathbf{9 7}$ & 100 \\
\hline
\end{tabular}

(Source: Own)

$U=(0,72-0,5) / \sqrt{\frac{0,5(1-0,5)}{97}}=4,31$

The result of the testing value $\mathrm{U}$ is greater than 1.645 , therefore, we can reject $\mathrm{H}_{0}$. We were able to show that Czech seniors distrust the investment environment including uncertainty of the return of investment in the Czech Republic. The set hypothesis was proved.

\section{VERIFICATION OF THE PROPOSED MODEL}

Verification of the Proposed Model - the Investment Potential of the Investor - is derived from Tables 1 and 2, which are listed and evaluated for Hypotheses 1 and 2. From Table 1, seniors who currently invest are important, at $7 \%$ of the investigated group; From Table 2, all data are used in relative terms, i. e., $32 \%$ of seniors willing to invest up to $500 \mathrm{CZK}, 31 \%$ up to $1,000 \mathrm{CZK}, 9 \%$ more than $1,000 \mathrm{CZK}$, and $28 \%$ not able to put aside a part of their personal pension or savings in to investment instruments.

We will use the present research and introduce the data gathered into the model, where we will assume that $7 \%$ of the investors who are willing to set aside more than 1,000 CZK are currently investing, see Table 1; they will be included in the model under Group no.1 among active investors. The other senior citizens who are willing to set aside part of their expenditures are included in the second group among potential investors including the $2 \%$ which stated that they put aside more than $1,000 \mathrm{CZK}$. The seniors who are not able to generate any savings are put into the last group in the model. The resulting data attained from the research are taken and applied to the model, which is depicted in Fig. 2. 
Figure 2 Applying the Model in Practice

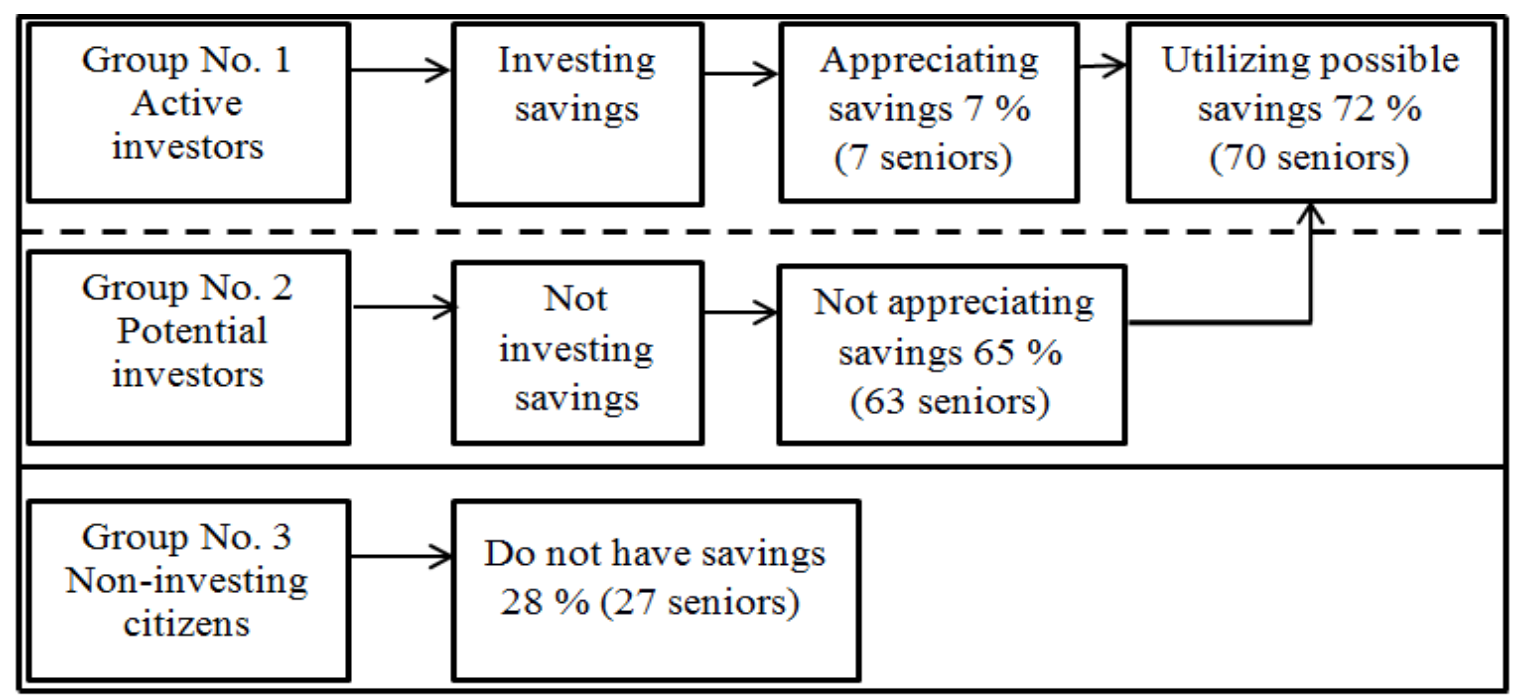

(Source: Own)

It is possible to express the results shown in the model in absolute values, where the most important is the second group of 63 seniors who do not use their financial resources. We can assume that the seniors in this group are willing to invest the average amount of $800 \mathrm{CZK}$ per month. Thus, these 63 respondents are currently not investing the amount of $50400 \mathrm{CZK}$ per month, which totals $604800 \mathrm{CZK}$ per year. The amount was set on the basis of data from the research with senior citizens.

We can also apply the data attained from the research that is listed in Fig. 2 to the overall population of seniors living in the Czech Republic - 7\% invest, $65 \%$ do not invest and $28 \%$ do not have savings. In the Czech Republic, the number of seniors receiving old-age pensions was 2340321 individuals as of Dec. 31, 2013. (ČSSZ, 2014) In Fig. 3, we see the model as applied to the overall population of senior citizens.

\section{Figure 3 Applying the Model for the Overall Population of Senior Citizens in the Czech Republic}

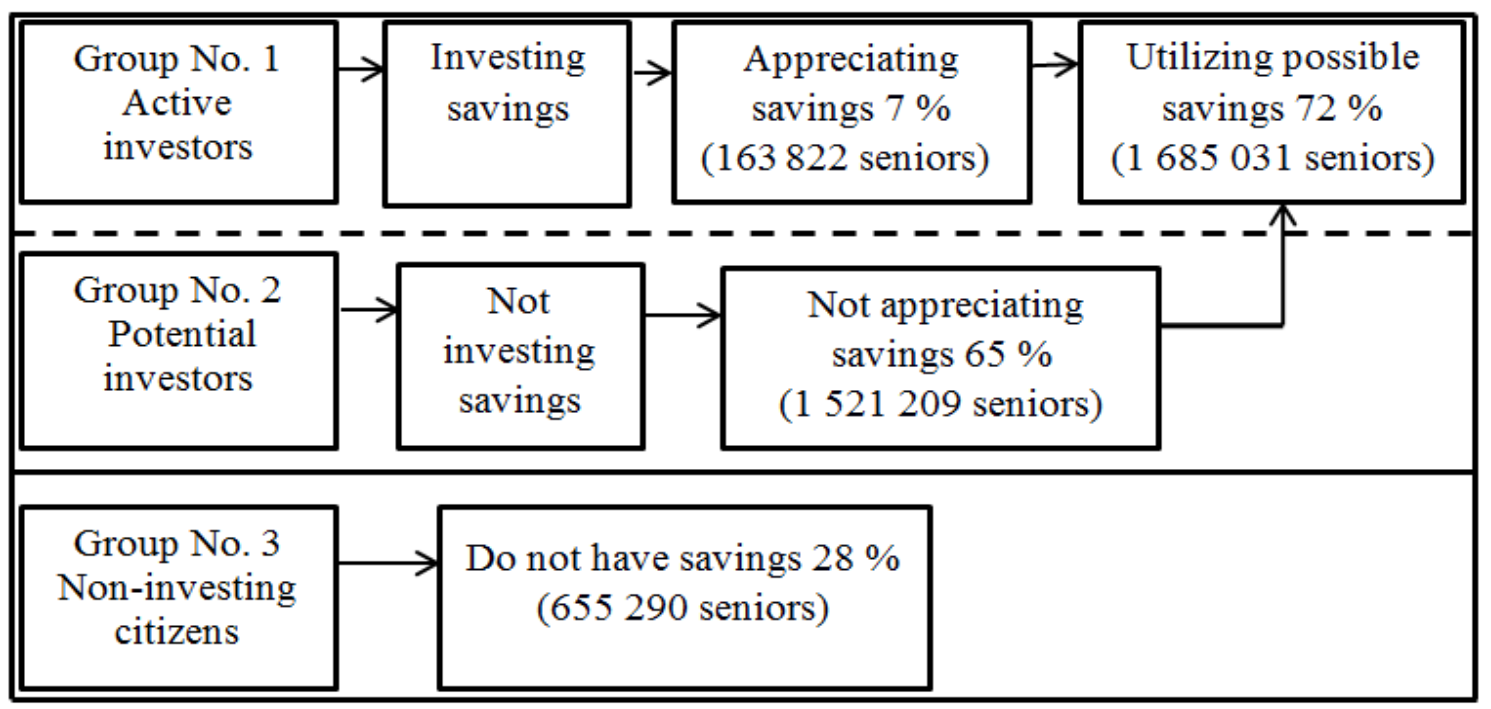

(Source: Own) 
As in the research conducted, the second group is also fundamental here on a country-wide basis. It includes all potential investors and comprises the largest number of seniors, which totals 1521209 in absolute terms. The assumption is that these investors can likewise invest the same amount of $800 \mathrm{CZK}$ that the respondents were willing to invest. The results show that $65 \%$ of Czech senior citizens do not use the overall amount of 1216967200 CZK per month, which totals $14603606400 \mathrm{CZK}$ per year.

\section{DISCUSSION}

As it has already been stated in the introduction, in the matter of resources owned by Czech seniors, the demand and a serious bid are not in balance. Not only mentioned trauma of voucher privatization, but also contemporary developments in the economic area affect their "investment courage."

At the end of 2014 most banks operating in the Czech Republic gave its clients a Christmas "gift" in the form of a notice of interest rate cuts. Such minimal appreciation of classical banking products has been reduced to almost insignificant value. Appeasement for seniors may be perhaps the fact that bank deposits are insured and therefore they should not lose them.

After all, money saved "under the pillow" at home is not the safest way too. Banks offer mediation called "safe investment" in the funds that manage their" daughters". However, one question arises here, what do they expect the funds to benefit from when their "mothers" fail? The answer is simple because they have only two options: speculation or government bonds.

The first case is unacceptable for the seniors because they would incur the risk of losing what have left to them. If the funds tout that they are secured against debacle, then only by using of theirs or "mother's" reserves. Of course, such protection may end badly because one always earns over the other on the secondary market. The second case-the use of investments in government bonds - is currently more common, less risky, but also less profitable. The functioning of this procedure, however, depends on the state's ability to earn for revenues they have to pay. They must not do gradual "rolling" or breaking one wedge by another over the budgets of the coming years. But the seniors will hardly be interested in the indebtedness of the next generation.

The business environment in the Czech Republic is divided between large, medium and small businesses. Unfortunately, most of them are not tradable on the stock exchange and the largest ones, mostly owned by foreign companies, leave nothing by using of effective optimization, except for social security and health security.

These two categories are also problem in the Czech Republic, regarding the demographic trends the social one is not good enough and the health one is not good enough too considering the previous solidarity in the health system. Thus there is not where the money and capital markets invest in the Czech Republic. Perspective is identical to the current situation. That is why a number of various fund managers uses the opportunities offered by foreign financial markets. It is certainly possible, if not the correct procedure, reducing the risk according to Markowitz portfolio theory (to minimize the positive correlation between investments). There are, however, investors (our seniors), entirely in the hands of those who can read foreign markets and can (at least they think so) predict their movements. Anyway, most seniors are still not able to make their own investment choices and to take care of their resources regularly.

The problem is global economic development, which globalize rapidly and it causes that the mentioned necessary negative correlation gets cracked. There are more and more companies that 
provide everything from raw material extraction to the final most complex products. Most of the state budget deficit is growing, not only in the EU. Thus an uncertain period is waiting for the seniors, regarding the multiplication of existing savings as well as the upcoming savings and the certainty of the primary resources.

If representatives of the Czech Republic together with investment companies do not start to deal with this matter to achieve savings being evaluated, there is a possibility that there will be more poor seniors because their savings will be devalued. These people cannot do without help from our state, which will burden the state budget. If we add demographic prognosis for the Czech Republic and EU, then young generation will not be able to support the seniors receiving an old age pension, which could lead to citizens at productive age leaving for countries where better living conditions than just to work for older citizens will be offered to them.

\section{CONCLUSIONS}

The research conducted using seniors has contributed new findings about this segment of investors. These findings confirmed or refuted the set hypotheses. The main finding resulting from the research was that the majority of seniors can put aside a part of their expenditures for investment but are not yet able to sufficiently use their investment potential. The proposed model confirmed this and was also applied to senior citizens on a country-wide scale.

The investigated sample of respondents represented 97 senior citizens; nonetheless, this research can be considered representative, because it was confirmed by the formula for an unknown composition of respondents. The limitations of the research can be seen in the fact that it covered only part of the Czech Republic's territory. In order to establish results with greater objectivity, it would be appropriate to expand the investigated sample to other parts of the Czech Republic. Therefore, the subject of further research will be to gradually expand the sample of respondents and thus attain results of a higher quality.

Professional literature primarily discusses and describes in detail demographic changes, social services, active aging and health care for senior citizens. However, the Czech market environment almost entirely lacks any type of description of investment products and strategies for appreciating available financial resources specifically for senior citizens. Omitting the senior segment is not directly on target with respect to their growing numbers in society, which was confirmed by the research conducted. The proposed model and its application in practice clearly demonstrate the substantiation and significance of this investigated segment, which is full of considerable financial potential. Advantages can be seen in the fact that most monetary institutions are not concerning themselves with this group of customers at all. This thereby creates business opportunities on the market for financial entities that can fill this market gap in time and utilize it to their own entrepreneurial advantage.

This problematic definitely deserves more attention not only in the area of theory but also in practical application. There are definite ways here to develop the investigated problematic to allow it to gain popularity at an investment firm. It is theoretically advisable for the expansion of the investing public to include senior segment investment in investment instruments to be supported by publishing activities relating to retirement-age investing. Investment entities having practical experience with investing seniors should supplement the quality of such publishing activities. It is also possible to conduct further marketing research for this segment of customers. The results of such research could bring new findings and thereby support the popularity of investment by senior citizens. 


\section{REFERENCES}

BANKOVNÍ POPLATKY (2012). Available from ww: <http://www.bankovnipoplatky.com/banky-a-klienti-seniori-16596.html>.

Bartoňová, D. (2010) Demografická situace České republiky proměny a kontexty 1993-2008. 1st ed. Prague: Sociologické Nakladatelství (SLON), 238 p. ISBN: 978-80-7419-024-7

Bočková, L., Hastrmanová, Š., Havrdová, E. (2011) 50+ aktivně fakta, inspirace a rady do druhé poloviny života. Prague: Respekt Institut, 95 p. ISBN: 978-80-904153-2-4

BUSINESS STANDARD (2013). Available from www: <http://www.businessstandard.com/article/pf/investment-options-for-retired-people-113071700163_1.html>.

CANADIANLIVING (2014). Available from ww: <http://www.canadianliving.com/life/money/the_best_investment_options_for_aging_canadi ans.php>.

CANADIANMONEYSAVER (2014). Available from ww: $<$ http://www.canadianmoneysaver.ca/the-best-interest-standards-and-the-elderly/>.

CAREGIVERS (2014). Available from www: <http://www.caregivers.com/senior-citizens2/secure-financial-investments/>.

ČSSZ (2014). Available from www: <http://www.cssz.cz/cz/o-cssz/informace/media/tiskovezpravy/tiskove-zpravy-2014/2857856-duchodcu-evidovala-cssz-k-31-12-2013.htm>.

Dvořáčková, D. (2012) Kvalita života seniorů v domovech pro seniory. 1st ed. Prague: Grada Publishing, 112 p. ISBN: 978-80-247-4138-3

ECONOMICTIMES (2010). Available from www <http://articles.economictimes.indiatimes.com/2010-12-19/news/27609892_1_seniorcitizens-investor-cash-flows>.

EHOW (2014). Available from www: <http://www.ehow.com/list_6588666_safe-investmentsseniors.html>.

Gruss, P. (2009) Perspektivy stárnutí z pohledu psychologie celoživotního vývoje. 1st ed. Prague: Portál, 222 p. ISBN: 978-80-7367-605-6

Hindls, R. et al. (2006) Statistika pro ekonomy. 7th ed. Prague: Professional Publishing, 415 p. ISBN 80-86946-16-9

IDNES (2013). Available from www: <http://finance.idnes.cz/cesti-seniori-by-meli-sporitodvazneji-tvrdi-odbornici-piz-/spor.aspx?c=A110822_143623_spor_bab>.

INVESTUJEME (2013). Available from www: <http://www.investujeme.cz/vetsina-senioru-usetrimesicne-maximalne-1-500-korun/>.

Klufová, R., Poláková, Z. (2010) Demografické metody a analýzy demografie české a slovenské populace. 1st ed. Prague: Wolters Kluwer Czech Republic, 306 p. ISBN: 978-80-7357-546-5

Kozel, R. (2006) Moderní marketingový výzkum: nové trendy, kvantitativní a kvalitativní metody a techniky, průběh a organizace, aplikace v praxi, přinosy a možnosti. 1st ed. Prague: Grada Publishing, 277 p. ISBN 80-247-0966-X

MINISTRY OF LABOUR AND SOCIAL AFFAIRS OF THE CZECH REPUBLIC (2008). Quality of life in old age National programme of preparation for Ageing for 2008-2012. 1st ed. Prague: Ministry of Labour and Social Affairs, 58 p. ISBN: 978-80-86878-66-9

MONEYOVER55 (2014). Available from ww: <http://moneyover55.about.com/od/howtoinvest/a/retirementinvestments.htm>.

MONEY Retirement (2014).Available from ww: <http://money.usnews.com/money/retirement/articles/2014/01/27/how-seniors-are-payingfor-retirement $>$.

Pecáková, I. (2011) Statistika v terénních průzkumech. 2nd ed. Prague: Professional Publishing, 236 p. ISBN 978-80-7431-039-3

PENÍZE (2009). Available from www: <http://www.penize.cz/prime-bankovnictvi/48813-bankyprodukty-pro-mlade-ano-pro-seniory-ne $>$. 
PODNIKATEL (2013). Available from www: <http://www.podnikatel.cz/clanky/pece-o-seniorylukrativni-byznys-budoucnosti/>.

Polách, J., Drábek, J., Merková, M., Polách, J. jun. (2012) Reálné a finanční investice. Praha: C.H. BECK, 264 p. ISBN 978-80-7400-436-0

Riedl, A. (2012) Senior - zákazník budoucnosti marketing orientovaný na generaci 50+. 1st ed. Brno: BizBooks, 256 p. ISBN: 978-80-265-0018-6

Roubíček, V. (1997) Úvod do demografie. 1st ed. Prague: Codex Bohemia, 348 p. ISBN: 80-8596343-4

SECURITIES AND EXCHANGE COMMISSION (SEC) (2014). Available from www: <http://www.sec.gov/reportspubs/investor-publications/guideforseniors.pdf >.

Sejkora, F. (2013) Analysis of the Causes of the Low Number of IPOS at Prague Stock Exchange compared to Polish Stock Exchange. Pardubice: Scientific Papers, vol. XX, no. 26, pp. 160169, ISSN 1211-555X

SENIOR LIVING (2014). Available from www: <http://www.seniorlivingmag.com/articles/activeversus-passive-investing>.

Syrový, P. (2012) Jak spořit na důchod. 1st ed. Prague: Grada Publishing, 160 p. ISBN: 978-80247-4479-7

Vlachynský, K. (2013) Dochodková nerovnost' a jej zmierňovanie. Bratislava: VedeckýčasopisFakultypodnikovéhomanažmentuEkonomickejuniverzity, vol. X, no. 2, pp. 7 - 20. 115 p. ISSN: 1336-3301 